\title{
INTERPOPULATIONAL VARIABILITY OF PINUS SYLVESTRIS L. IN EIGHT POLISH LOCALITIES EXPRESSED IN MORPHOLOGICAL AND ANATOMICAL TRAITS OF NEEDLES
}

\author{
MARIA ANNA BOBOWICZ ${ }^{1}$ and ADOLF F. KORCZYK ${ }^{2}$ \\ 'Department of Genetics, Adam Mickiewicz University, \\ Dąbrowskiego 165, 60-594 Poznań, Poland \\ ${ }^{2}$ Natural Forest Department, Forest Research Institute, \\ Park Dyrekcyjny, 17-230 Białowieża, Poland
}

(Received: March 26, 1991. Accepted: May 17, 1994)

\begin{abstract}
Two-year old needles were collected from 272 standing trees of Pinus sylvestris L., representing 8 Polish populations. The needles were studied in respect to 15 morphological and anatomical traits. The obtained data were subjected to multivariate statistical analysis in an attempt to delineate interpopulational variability. Multivariate analysis of variance with testing of statistical hypotheses and discriminant analysis were conducted. Mahalanobis distances were calculated between each of population in pairs and their significance was estimated using Hotelling $\mathrm{T}^{2}$ statistics. On the basis of the shortest Mahalanobis distances a minimum spanning tree was constructed and on the basis of Euklidean distances hierarchy grouping was performed. A large majority of the populations was found to differ significantly from the remaining populations. The population from Bolewice proved to be most divergent. The principal variables which proved capable of discriminating between populations were found to include: needle length, the number of stomata on the flat side of the needle and the number of resin canals. Using Bryant's test, the studied populations were found to belong to two geographic groups: the North-Polish one or the South-Polish one.
\end{abstract}

KEY WORDS: Pinus sylvestris L., populations, needles, variability, multivariate analysis

\section{INTRODUCTION}

The paper work presents part of a broader study on individual and populational variabilities of Pinus sylvestris L. in eight national populations (Fig. 1), i.e. those originating from forest districts in Miłomłyn, Ruciane, Supraśl, Bolewice, Gubin, Rychtal and Janów Lubelski (Korczyk 1975), characterized more closely in Material and Methods. Pines from the biotopes belong among the best ones in Poland, in respect to their cultural quality, as indicated by both the results of national population experiments (Tyszkiewicz et al. 1967, Przybylski 1970, Gunia 1973, Kocięcki 1973, Rzeźnik 1973, Chodzicki 1978, Cierniewski and Przybylski 1978, Sabor and Stachnik 1990) and the results of IUFRO experiments from 1938 and 1939, presented by Giertych $(1979,1980)$. Interpopulational enzymatic variability of $P$. sylvestris L., in eight Polish populations has been presented in papers of Krzakowa $(1979,1980,1982)$, variability in respect to phenol compounds has been examined by Krzakowa et al. (1990) while the variability expressed in morphological traits of cones has been examined in the study of Bobowicz and Korczyk (1994).

*In this paper the term population indicates tree sample drawn at random from a given biotope.

\section{MATERIAL AND METHODS}

In 1976, one stand of trees with the oldest (75 to 248 years) pine trees within a given forest district was chosen in each of 8 selected populations* (Fig.1). It was assumed that in this way the autochtonous pine populations may be chosen which arose by natural renewal. The tree stands grew in the same type of biotope - the fresh mixed forest.

Localities and short characteristics of selected populations: 1. Forest district Miłomłyn, section 107b, nature reservation, a pine-oak-beech stand at a mixed forest site with a brown, leached soil, originating from argillaceous sands. Age of the selected trees ranged between 192 and 248 years. Pines in the stand were accepted as autochtonous and originating from a natural renewal. 2. Forest district Ruciane, section $89 a$, seed production stand of pines in a biotope of a mixed, fresh forest with a grassland, weakly podsolized soil, originating from weakly argillaceous sands. Age of the trees ranged between 91 and 207 years. Autochtonous pines from natural renewal. 3. Forest district Supraśl, section 157b, pine stand in a mixed forest biotope, with a brown, weakly podsolized soil originating from argillaceous sands of medium depth. Age of the selected trees ranged between 143 and 189 years. Autochtonous pine from natural renewal. 4. Forest district Supraśl, section $174 \mathrm{fg}$, seed production stand of pines in a mixed forest biotope, originating from weakly argillaceous sands interbedded 


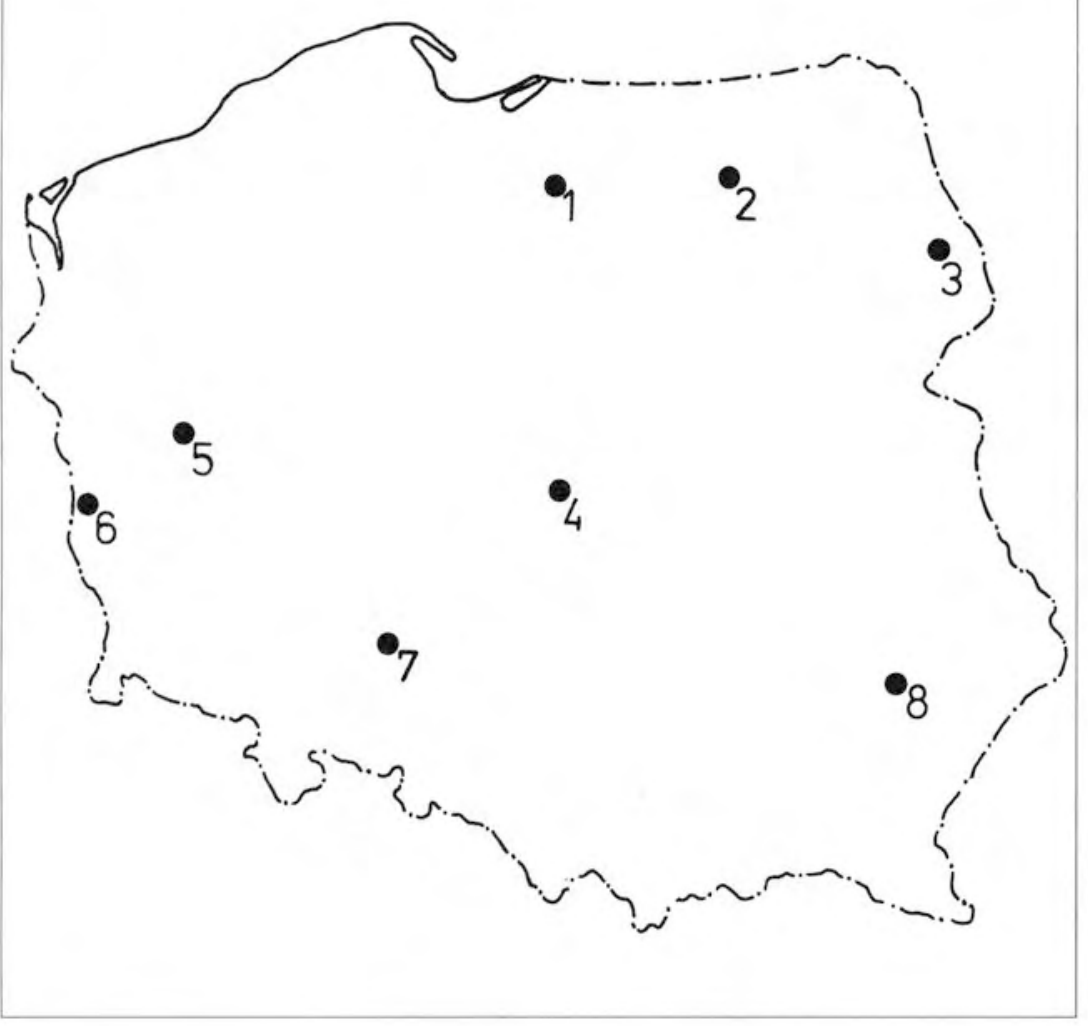

Fig. 2. Localization of studied populations: 1 - Miłomłyn, 2 - Ruciane, 3 - Supraśl, 4 - Spała, 5 - Bolewice, 6 - Gubin, 7 - Rychtal, 8 - Janów Lubelski.

with firm argillaceous sands of medium depth. Age of the trees ranged from 128 to 179 years. Autochtonous pines from natural renewal. 5. Forest district Bolewice, section 253d, seed production stand of pines in a biotope of fresh mixed forest with a weakly podsolized soil originating from light and deep argillaceous sands. Age of the trees ranged between 75 and 103 years. Planted pines, probably of autochtonous origin. 6. Forest district Gubin, section 145bf, seed production stand of pines in a biotope of a fresh mixed forest with a weakly podsolized soil, originating from sands of variable granulation with admixture of gravel. Age of the trees ranged between 136 and 191 years. Autochtonous pines from natural renewal. 7. Forest district Rychtal, section $75 \mathrm{gh}$, seed production stand of pines in the biotope of a fresh mixed forest with soils of the proper podsole type, weakly podsolized originating from light and deep argillaceous sands. Age of the selected trees ranged between 84 and 119 years. Planted pines, probably of autochtonous origin. 8. Forest district Janów Lubelski, section 63h, 93, a fir-pine stand in a biotope of a mixed forest with a weakly podsolized podsole, originating from intensely humid argillaceous sands. Age of the trees ranged between 94 and 168 years. Autochtonous pines from natural renewal.

A linear transect was run through each set of trees and 40 trees were drawn at random along the transect. Each tree was accurately measured and described, defining its age by sampling the trunk at breast height. In 1977, two-year old needles and cones were collected from the standing trees. The needles were collected from a total of 272 trees. From unshaded branches of the Ist order, growing at the peak of tree head, 2720 sprouts were collected in which the following 15 traits were measured:

1. needle length $(\mathrm{mm})$,

2. number of stomatal rows on the convex side of the needle,
3. number of stomatal rows on the flat side of the needle,

4. number of stomata in a $2 \mathrm{~mm}$ long section on the convex side of the needle,

5. number of stomata in a $2 \mathrm{~mm}$ long section on the flat side of the needle,

6. number of resin canals,

7. crossection width of the needle, in $\mu \mathrm{m}$,

8. crossection height of the needle, in $\mu \mathrm{m}$,

9. distance between vascular bundles, in $\mu \mathrm{m}$,

10. height of epidermis cell, in $\mu \mathrm{m}$,

11. width of epidermis cell, in $\mu \mathrm{m}$,

12. Marcet coefficient (Marcet 1967): trait $7 \times$ trait 9

13. trait 2 trait 8

14. trait 8

trait 7

15. $\frac{\text { trait } 11}{\text { trait } 10}$

Results of measurements were transferred to the Computing Center, Agricultural School in Poznań and to the Center of Informatics, Adam Mickiewicz University in Poznań. They served to calculate:

1. characteristics of the applied 15 needle traits,

2. correlation coefficients between the trait values,

3. discriminant power of the traits,

4. multivariate analysis of variance with statistics hypothesis testing,

5. discriminant analysis,

6. Mahalanobis distances with Hotelling $\mathrm{T}^{2}$ statistics,

7. minimum spanning tree constructed on the basis of the shortest Mahalanobis distances, 
8. agglomerative grouping by the method of the closest neighbourhood on the basis of Euklidean distances (dendrogram).

Geographic variability was defined using Bryant's test (1977).

\section{RESULTS}

As shown by the trait characteristics (Table 1), trait variability in the studied eight populations ranged between $3.00 \%$ and $23.68 \%$. The highest variability coefficient was observed in the most variable trait in all populations (except trait 1 in

TABLE 1. Means (I), standard deviations (II), variability indices (III), minimum (IV) and maximum (V) values (A) for 15 needle traits (B) of 8 Polish populations (C) of Pinus sylvestris L.

\begin{tabular}{|c|c|c|c|c|c|c|c|c|c|c|c|c|c|c|c|c|}
\hline A & $\begin{array}{l}\text { B } \\
\text { C }\end{array}$ & 1 & 2 & 3 & 4 & 5 & 6 & 7 & 8 & 9 & 10 & 11 & 12 & 13 & 14 & 15 \\
\hline \multirow{8}{*}{ I } & 1 & 48.18 & 10.55 & 9.94 & 21.07 & 21.33 & 10.75 & 1.39 & 0.66 & 0.22 & 20.61 & 15.77 & 0.45 & 1.07 & 0.48 & 0.77 \\
\hline & 2 & 56.20 & 10.70 & 10.04 & 21.29 & 21.91 & 11.11 & 1.47 & 0.70 & 0.24 & 21.88 & 15.72 & 0.51 & 1.08 & 0.48 & 0.74 \\
\hline & 3 & 52.93 & 11.15 & 10.28 & 23.87 & 24.24 & 11.59 & 1.45 & 0.69 & 0.23 & 20.73 & 15.65 & 0.47 & 1.10 & 0.48 & 0.76 \\
\hline & 4 & 65.72 & 11.72 & 11.13 & 23.35 & 24.13 & 12.27 & 1.45 & 0.70 & 0.23 & 19.57 & 15.13 & 0.48 & 1.07 & 0.48 & 0.77 \\
\hline & 5 & 68.33 & 10.45 & 9.70 & 20.05 & 20.37 & 10.73 & 1.44 & 0.69 & 0.22 & 20.04 & 15.74 & 0.46 & 1.10 & 0.48 & 0.79 \\
\hline & 6 & 53.97 & 10.05 & 9.37 & 23.38 & 24.09 & 10.90 & 1.39 & 0.65 & 0.20 & 20.98 & 15.50 & 0.43 & 1.09 & 0.47 & 0.74 \\
\hline & 7 & 61.71 & 10.91 & 10.36 & 24.26 & 24.77 & 11.24 & 1.38 & 0.66 & 0.21 & 19.89 & 15.03 & 0.44 & 1.07 & 0.48 & 0.76 \\
\hline & 8 & 60.01 & 11.24 & 10.43 & 23.77 & 24.61 & 12.53 & 1.43 & 0.70 & 0.22 & 19.89 & 15.36 & 0.47 & 1.09 & 0.49 & 0.78 \\
\hline \multirow{8}{*}{ II } & 1 & 6.33 & 1.37 & 1.10 & 1.17 & 1.24 & 1.32 & 0.08 & 0.05 & 0.03 & 1.26 & 0.93 & 0.06 & 0.10 & 0.02 & 0.05 \\
\hline & 2 & 7.88 & 1.35 & 1.40 & 1.13 & 1.56 & 1.59 & 0.12 & 0.05 & 0.05 & 2.42 & 0.78 & 0.11 & 0.08 & 0.02 & 0.05 \\
\hline & 3 & 7.01 & 1.13 & 0.82 & 1.58 & 1.73 & 2.14 & 0.10 & 0.05 & 0.04 & 1.46 & 0.95 & 0.08 & 0.09 & 0.02 & 0.04 \\
\hline & 4 & 7.28 & 1.44 & 1.65 & 2.24 & 1.23 & 2.13 & 0.13 & 0.06 & 0.04 & 1.37 & 0.93 & 0.10 & 0.08 & 0.02 & 0.04 \\
\hline & 5 & 7.89 & 1.42 & 1.45 & 2.00 & 2.01 & 1.49 & 0.14 & 0.05 & 0.04 & 1.70 & 1.12 & 0.10 & 0.09 & 0.02 & 0.06 \\
\hline & 6 & 9.31 & 1.09 & 1.08 & 1.40 & 1.22 & 1.47 & 0.10 & 0.04 & 0.03 & 1.58 & 1.13 & 0.07 & 0.09 & 0.01 & 0.06 \\
\hline & 7 & 8.66 & 0.96 & 1.07 & 1.50 & 1.44 & 1.59 & 0.10 & 0.03 & 0.03 & 1.71 & 1.12 & 0.09 & 0. & 0.02 & 0.06 \\
\hline & 8 & 6.74 & 1.37 & 1.31 & 1.33 & 1.30 & 2.33 & 0.11 & 0.04 & 0.04 & 1.18 & 0.92 & 0.11 & 0.08 & 0.03 & 0.05 \\
\hline \multirow{8}{*}{ III } & 1 & 13.13 & 13.00 & 11.08 & 5.55 & 5.80 & 12.29 & 5.97 & 7.6 & 12.75 & 6.13 & 5.89 & 13.9 & 8.97 & 4. & 5.86 \\
\hline & 2 & 14.02 & 12.59 & 13.99 & 5.29 & 7.13 & 14.34 & 8.2 & 6.72 & 20.41 & 11.06 & 4.96 & 22.59 & 7.51 & 4.37 & 6.94 \\
\hline & 3 & 13.25 & 10.16 & 7.97 & 6.62 & 7.15 & 18.43 & 7.17 & 7.20 & 17.33 & 7.03 & 6.06 & 17.90 & 7.75 & 3.47 & 4.92 \\
\hline & 4 & 11.08 & 12.32 & 14.85 & 9.58 & 5.10 & 11.37 & 8.99 & 8.29 & 17.40 & 6.99 & 6.17 & 19.97 & 7.26 & 4.63 & 5.23 \\
\hline & 5 & 11.55 & 13.59 & 14.98 & 9.97 & 9.86 & 13.86 & 9.43 & 7.22 & 18.72 & 8.47 & 7.13 & 21.24 & 7.91 & 4.28 & 8.05 \\
\hline & 6 & 17.25 & 10.83 & 11.52 & 6.01 & 5.07 & 13.45 & 6.89 & 5.59 & 14.57 & 7.54 & 7.29 & 16.51 & 8.46 & 3.00 & 7.77 \\
\hline & 7 & 14.03 & 8.83 & 10.31 & 6.19 & 5.83 & 14.16 & 7.08 & 5.22 & 16.58 & 8.60 & 7.43 & 19.51 & 7.67 & 5.04 & 7.69 \\
\hline & 8 & 11.23 & 12.14 & 12.54 & 5.60 & 5.28 & 18.62 & 7.67 & 6.13 & 19.43 & 5.96 & 6.01 & 23.58 & 7.41 & 5.26 & 5.93 \\
\hline \multirow{7}{*}{ IV } & 1 & 5.4 & 8.40 & 7.00 & 18.70 & 8.70 & & 1.2 & 0.56 & 0.17 & 17.50 & 14.20 & 0.35 & 0.84 & 0.44 & 0.65 \\
\hline & 2 & 39.10 & 8.40 & 7.80 & 19.40 & 19.10 & 8.90 & 1.22 & 0.61 & 0.14 & 18.80 & 14.14 & 0.27 & 0.88 & 0.42 & 0.64 \\
\hline & 3 & 40.70 & 8.70 & 9.00 & 20.80 & 21.30 & 8.40 & 1.24 & 0.57 & 0.17 & 18.36 & 14.33 & 0.34 & 0.91 & 0.46 & 0.66 \\
\hline & 4 & 47.50 & 8.60 & 8.10 & 12.70 & 21.10 & 8.90 & 1.22 & 0.57 & 0.15 & 17.47 & 13.33 & 0.30 & 0.89 & 0.44 & 0.70 \\
\hline & 5 & 46.30 & 7.10 & 6.80 & 9.20 & 9.40 & 6.80 & 1.09 & 0.56 & 0.12 & 16.85 & 14.25 & 0.23 & 0.93 & 0.44 & 0.64 \\
\hline & 6 & 36.30 & 7.90 & 8.00 & 21.10 & 21.50 & 8.50 & 1.25 & 0.59 & 0.15 & 18.41 & 13.70 & 0.32 & 0.86 & 0.44 & 0.64 \\
\hline & 7 & 43.80 & 8.40 & 8.50 & 21.40 & 22.00 & 8.50 & 1.11 & 0.56 & 0.12 & 17.11 & 12.45 & 0.22 & 0.91 & 0.43 & 0.63 \\
\hline & 8 & 48.80 & 8.60 & 8.10 & 21.20 & 22.10 & 8.40 & 1.20 & 0.63 & 0.17 & 17.64 & 13.42 & $0.34 \backslash$ & 0.93 & 0.41 & 0.69 \\
\hline \multirow{8}{*}{ V } & 1 & 62.60 & 13.10 & 11.90 & 24.40 & 25.60 & 13.80 & 1.52 & 0.76 & 0.26 & 22.83 & 18.25 & 0.57 & 1.26 & 0.52 & 0.88 \\
\hline & 2 & 72.30 & 13.40 & 13.60 & 24.40 & 25.10 & 16.80 & 1.66 & 0.81 & 0.36 & 29.53 & 17.63 & 0.80 & 1.22 & 0.51 & 0.84 \\
\hline & 3 & 68.60 & 13.60 & 12.10 & 27.80 & 29.60 & 17.30 & 1.64 & 0.81 & 0.31 & 24.67 & 18.56 & 0.66 & 1.27 & 0.53 & 0.82 \\
\hline & 4 & 77.10 & 15.60 & 14.50 & 27.10 & 26.50 & 16.60 & 1.70 & 0.81 & 0.30 & 21.92 & 16.80 & 0.69 & 1.26 & 0.53 & 0.84 \\
\hline & 5 & 85.50 & 14.10 & 12.90 & 22.60 & 23.30 & 13.70 & 1.74 & 0.82 & 0.31 & 23.97 & 12.67 & 0.66 & 1.34 & 0.53 & 0.99 \\
\hline & 6 & 73.70 & 12.80 & 12.30 & 26.90 & 27.00 & 15.80 & 1.60 & 0.72 & 0.27 & 24.94 & 18.30 & 0.62 & 1.26 & 0.50 & 0.85 \\
\hline & 7 & 80.10 & 13.10 & 12.40 & 26.60 & 28.60 & 17.40 & 1.52 & 0.72 & 0.27 & 23.19 & 16.68 & 0.62 & 1.24 & 0.53 & 0.90 \\
\hline & 8 & 72.80 & 14.20 & 13.30 & 26.40 & 27.20 & 18.20 & 1.65 & 0.80 & 0.34 & 22.13 & 17.78 & 0.76 & 1.27 & 0.53 & 0.88 \\
\hline
\end{tabular}

Populations: 1 - Miłomłyn $\mathrm{n}=33,2$ - Ruciane $\mathrm{n}=33, \quad 3$ - Supraśl $\mathrm{n}=30,4-$ Spała $\mathrm{n}=33, \quad 5-$ Bolewice $\mathrm{n}=43$, $6-$ Gubin $\mathrm{n}=37, \quad 7-$ Rychtal $\mathrm{n}=34, \quad 8-$ Janów Lubelski $\mathrm{n}=29$.

Traits: $7,8,9$ and 12 are listed in $\mathrm{mm}$. 
the population from Gubin and trait 3 in the population from Supraśl). It involved the Marcet coefficient. In the population from Janów Lubelski it reached the value close to $24 \%$. The lowest variability in all populations was shown by the ratio of needle height at its crossection to its width. The lowest value of variability coefficient (3\%) was observed in the population from Gubin.

Out of 105 examined correlation coefficients, most or 49 (46.67\%) significant correlation coefficients (both at 0.01 and 0.05 levels) were noted in the population from Bolewice and the lowest number or $31(29.53 \%)$ was observed in the population from Supraśl. At the 0.01 level, the highest number or $43(40.95 \%)$ of the correlation coefficients were detected in the population from Bolewice and the lowest number or 17 $(16.19 \%)$ - in the population from Janów Lubelski. In all the populations the most strongly correlated traits included the distance between vascular bundles and the Marcet coefficient. Correlation coefficient between the traits showed values between 0.96 in the populations from Miłomłyn and Rychtal and 0.96 in the populations from Ruciane, Supraśl, Bolewice, Gubin. Total absence of significant correlations was detected between number of stomata either on the convex or on the flat sides of the needle and the remaining traits in the population from Spała and between the number of resin canals and the remaining traits in the populations from Rychtal and Janów Lubelski. The traits which were least correlated with the remaining ones (correlation coefficients lower than 0.01) included the number of stomata on the flat side of the needle and the height of the epidermis cell in the population from Spała as well as the former trait and Marcet coefficient in the population from Rychtal, the number of resin canals and the Marcet coefficient in the population from Rychtal, the distance between vascular bundles and the width of epidermis cell in the population from Janów Lubelski. Most or 13 $(12.38 \%)$ very low correlations (below 0.01 ) were noted in the population from Rychtal. Populations from Gubin and Janów Lubelski exhibited $7(6.67 \%)$ and $6(5.71 \%)$, respectively, of such correlation coefficients.
The discriminant power test (Caliński et al.1974) ascribed the principal role in differentiating the studied pine populations to needle length, number of stomata on the flat side of the needle and to the number of resin canals. Among the traits, needle length showed a particularly high value of statistics $\mathrm{F}$ (Table 2). All the remaining traits were of an associative significance.

In testing both general and detailed hypotheses in multivariate analysis of variance (Caliński 1970, Caliński et al. 1976, Ceranka etal. 1976), out of 15 applied needle traits only those traits were taken into account which were found dominant in the discriminant power test (traits 1,5 and 6). Testing of the hypotheses indicated that out of 28 contrasts or comparisons of population pairs only 4 contrasts were not significantly differentiated $\left(\mathrm{F}_{0.05}>\mathrm{F}_{\text {calc }}\right)$ : Rychtal - Janów Lubelski, Supraśl - Gubin, Spała - Janów Lubelski and Spała - Rychtal. The remaining 24 contrasts were significantly differentiated $\left(\mathrm{F}_{\text {calc }}\right.$ $>\mathrm{F}_{0.05}$ ). Three of them, i.e. Miłomłyn - Spała, Bolewice Janów Lubelski and Miłomłyn - Janów Lubelski differed significantly in respect to all three principal variables $(1,5,6)$. The highest values of statistics $\mathrm{F}$ were shown by the trait 5 (the number of stomata on the flat side of the needle) which differed significantly in 17 contrasts. Trait 1 (needle length) differed significantly in 19 contrasts but the highest value of statistics $\mathrm{F}$ was lower almost by half from the highest value of statistics $\mathrm{F}$ for trait 5 . Trait 6 (number of resin canals) differed significantly in only 7 contrasts. The highest value of statistics $\mathrm{F}$ was almost 14-fold lower than the highest value of statistics $F$ in trait 5 . The highest values of statistics $F$ were reached by the contrasts in which the population from Bolewice was compared.

Graphically detected variability between eight populations was presented in the space of the first three discriminant variables $\mathrm{U}_{1}, \mathrm{U}_{2}, \mathrm{U}_{3}$ (Fig. 2), calculated in the discriminant analysis (Caliński and Kaczmarek 1973, Caliński et al. 1975, Krzyśko 1979,1982). The studied populations were discriminated into 3 groups. The first was formed by the populations from Miłomłyn, Ruciane and Bolewice. The latter population

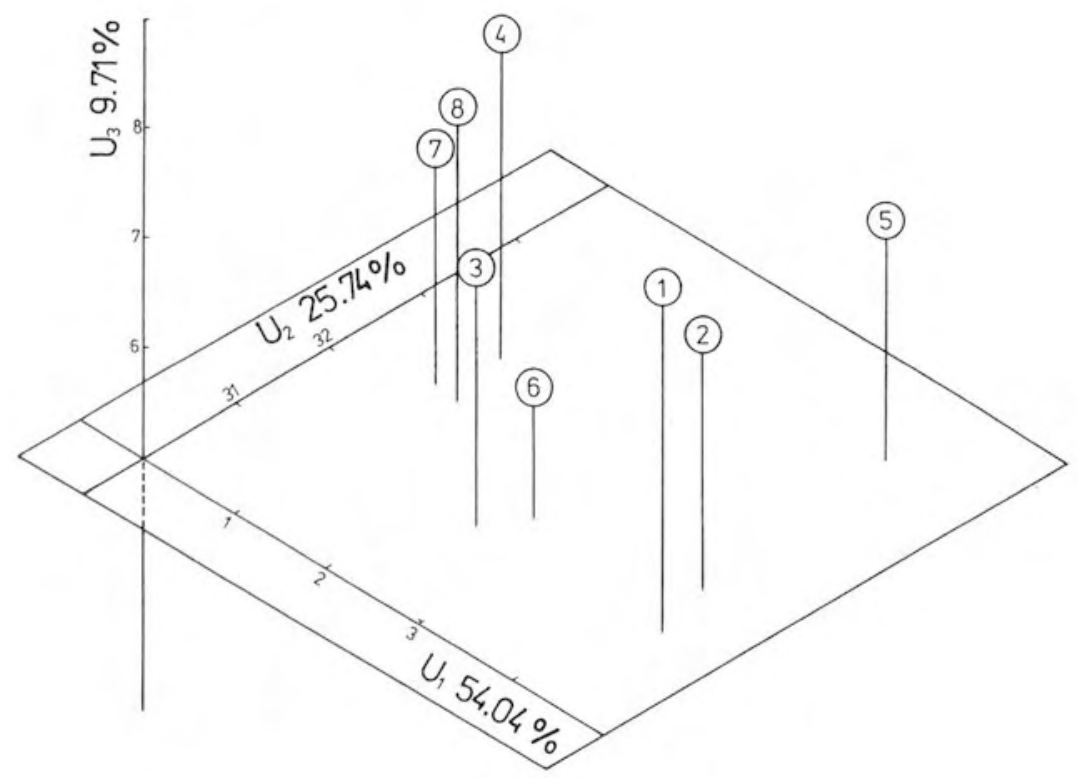

1 - Miłomłyn

2 - Ruciane

3 - Supraśl

4 - Spała

5 - Bolewice

6 - Gubin

7 - Rychtal

8 - Janów Lubelski

Fig. 2. Results of discriminant analysis of eight populations of Pinus sylvestris L. (in brackets: number of studied tress) in the space of the first three discriminant variables $\mathrm{U}_{1}, \mathrm{U}_{2}, \mathrm{U}_{3}$, containing altogether $89 \%$ information of the applied set of 15 needle traits. 


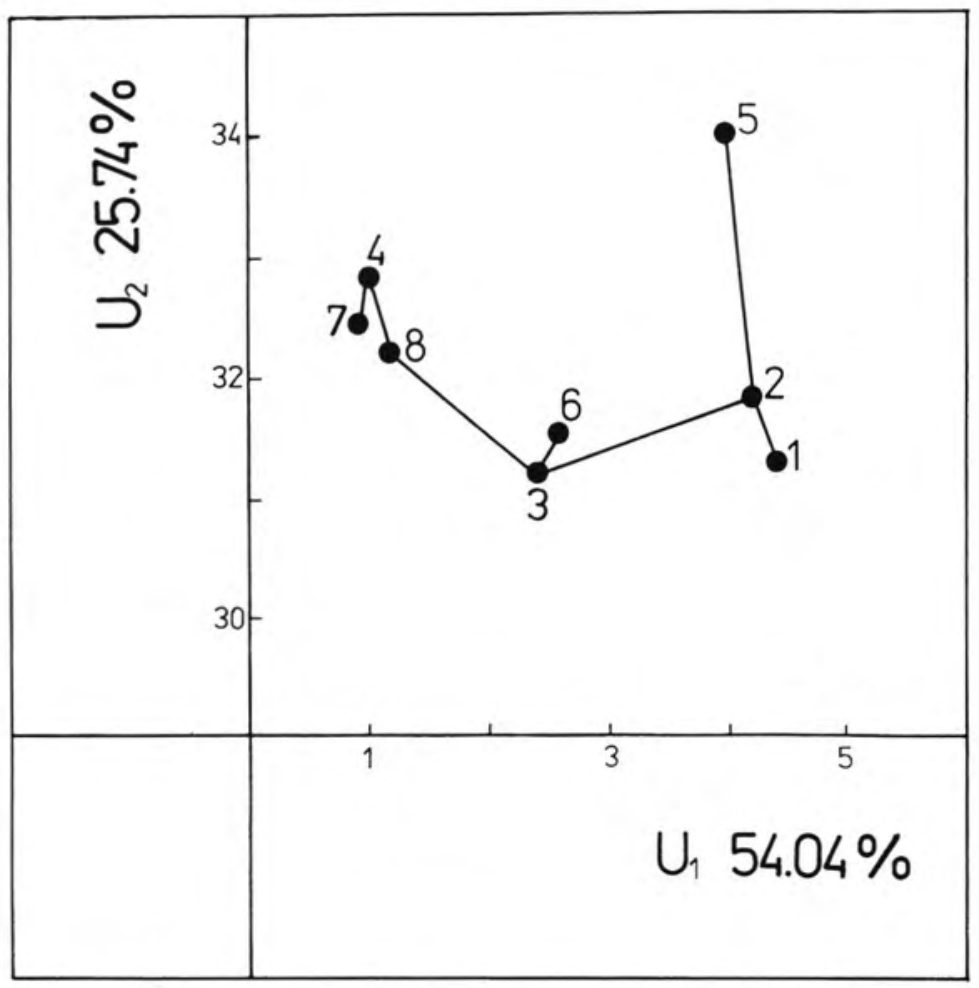

Fig. 3. Results of discriminant analysis in eight populations of Pinus sylvestris L. (described in Fig. 2) on the plane of the first two discriminant variables $\mathrm{U}_{1}, \mathrm{U}_{2}$ (close to $80 \%$ information of the applied set of 15 needle traits) linked into the minimum spanning tree by the shortest Mahalanobis distances. was very distant from the populations from Ruciane and from Miłomłyn. The other group was formed by the populations from Supraśl and Gubin. The third group was formed by the populations from Spała, Rychtal and Janów Lubelski. The described above discrimination was particularly evident on the plane of the first two discriminant variables $\mathrm{U}_{1}, \mathrm{U}_{2}$ (Fig. 3).

On the basis of the determination coefficients between 15 needle traits and the first three discriminant variables, the variability pattern obtained in Fig. 2 may be regarded to be determined mainly by the numbers of stomata on the flat and the convex sides of the needle, needle length and the numbers of stomal rows on the flat and the convex side of the needle.

The minimum spanning tree constructed on the basis of the shortest Mahalanobis distances (Caliński et al. 1975) and Hotelling $\mathrm{T}^{2}$ statistics are shown in Fig. 4. Comparison of the calculated values Hotelling $\mathrm{T}^{2}$ statistics with their respective critical value indicated that none of the population pairs forming the tree was significantly differentiated $\left(\mathrm{T}_{0.05}^{2}>\mathrm{T}^{2}\right.$ calc).

Mahalanobis distances between each two populations out of the eight examined populations are listed in Table 3. On the basis of the distances it was concluded that the population from Bolewice significantly differed from the highest number of the remaining populations, i.e. from 5 out of 7 populations. It did not differ significantly only from the populations from Miłomłyn and Ruciane. The highest significant Mahalanobis distance linked the population from Bolewice and the population from Rychtal. It amounted to 3.52 and was the second in length Mahalanobis distance in the table of the links (Table 2). The population from Miłomłyn differed significantly from the populations from Spała, Rychtal and Janów Lubelski. Distance between the population from Miłomłyn and the population from Spała was the greatest Mahalanobis distance in the entire table of links. It amounted to 3.78 . The population from Ruciane differed significantly from the populations from Spała and from Rychtal. Mahalanobis distance between $\mathrm{Ru}-$ ciane and Spała populations was 3.47 and almost equalled the Mahalanobis distance between Ruciane and Rychtal populations which was 3.46 .
TABLE 2. Results of testing discriminant power of 15 traits of needles originating from eight Pinus sylvestris L. populations

\begin{tabular}{cc}
\hline Traits & F statistics \\
\hline 1 & $27.034^{*} *$ \\
2 & $1.260^{*}$ \\
3 & $0.422^{*}$ \\
4 & $1.417^{*}$ \\
5 & $7.921^{*}$ \\
6 & $3.937^{*}$ \\
7 & $0.757^{*}$ \\
8 & $1.167 *$ \\
9 & $1.237^{*}$ \\
10 & $1.589 *$ \\
11 & $0.789 *$ \\
12 & $0.961 *$ \\
13 & $1.141 *$ \\
14 & $1.212^{*}$ \\
15 & $0.308^{*}$ \\
\hline
\end{tabular}

** principal variables, $*$ associative variables

The dendrogram, constructed on grounds of agglomerative grouping using the method of the closest neighbourhood, based on Euklidean distances (Karoński and Caliński 1973) is presented in Fig. 5. As shown in the Figure, the studied populations formed two groups: one including the populations from Supraśl Gubin, Ruciane $(3,6,2)$ and the other including the populations from Janów Lubelski, Rychtal and Spała. The populations from Bolewice and Miłomłyn failed to fit any of the groups.

In the minimum spanning tree projected onto the biotope map of the eight populations (Fig. 6), the three north-eastern populations, i.e. the populations from Miłomłyn, Ruciane and Supraśl are linked to each other. In addition, the population 


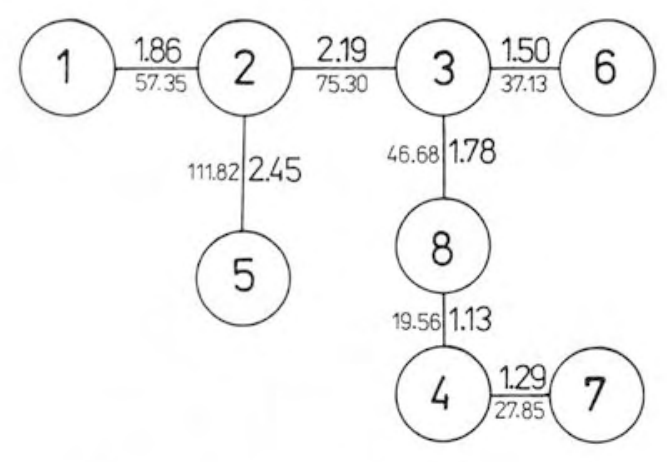

$$
T_{0.05}^{2}=171.686
$$

Fig. 4. Minimum spanning tree of eight populations of Pinus sylvestris L. (described in Fig. 2) constructed on the basis of the shortest Mahalanobis distances. Each distance between two populations is additionally described by Hotelling $\mathrm{T}^{2}$ statistics (small print). $\mathrm{T}^{2} 0.05$ denotes the critical value of Hotelling's statistics.

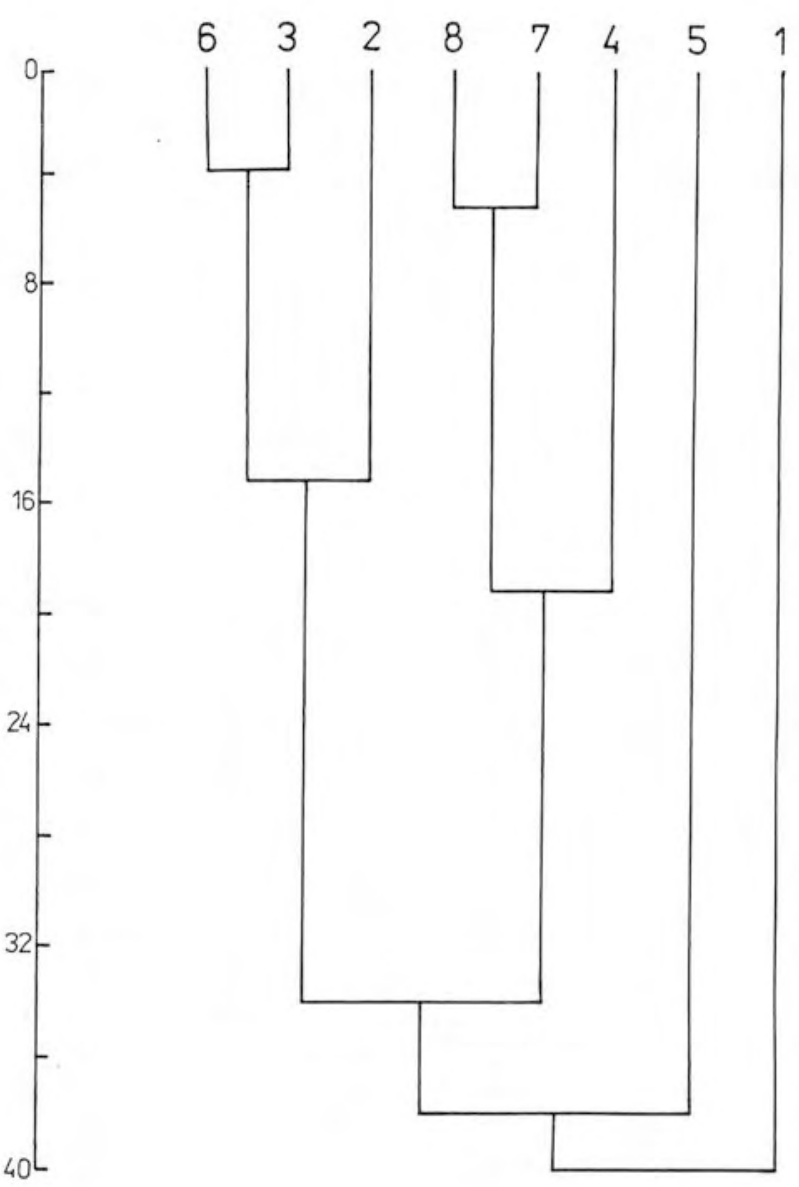

Fig. 5. Dendrogram of eight Pinus sylvestris L. populations (described in Fig. 1) constructed on the basis of the shortest Euklidean distance.

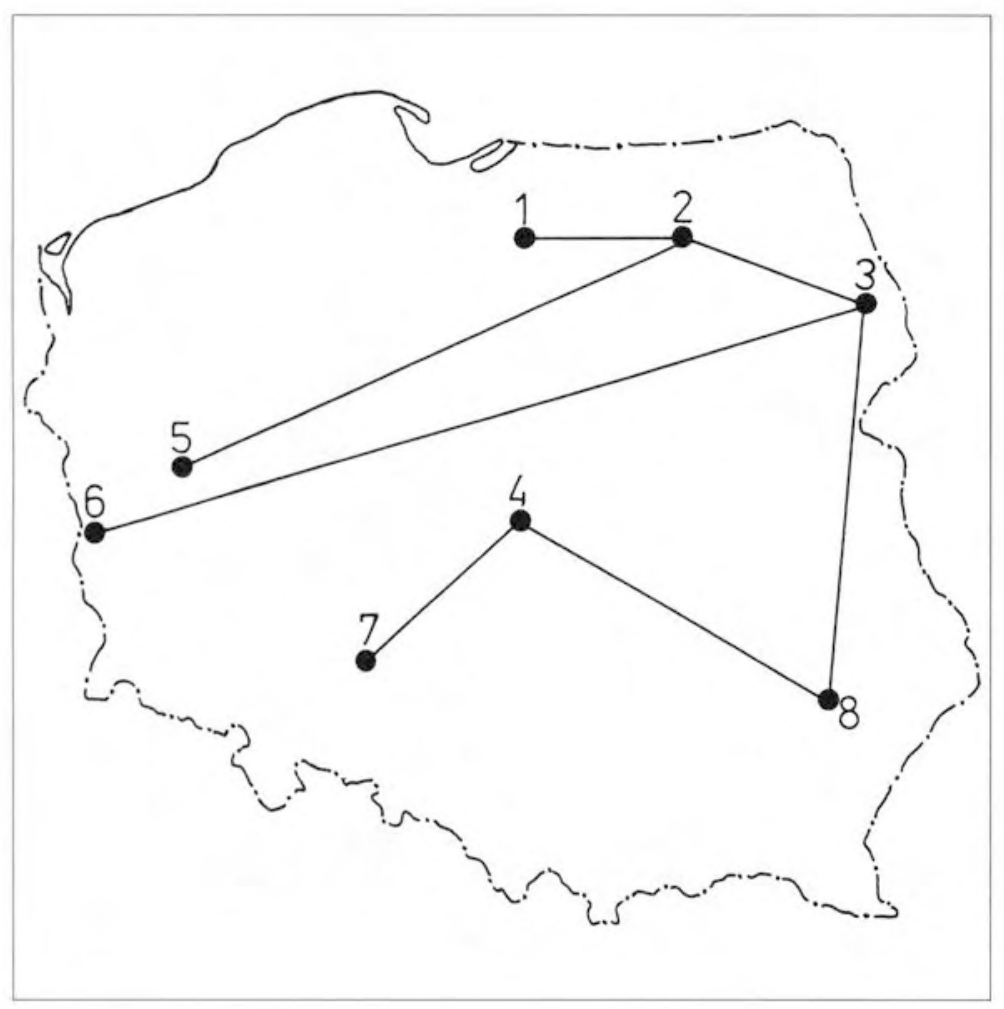

Fig. 6. Minimum spanning tree of eight Pinus sylvestris L. populations (described in Fig. 1) defined by the shortest Mahalanobis distances and projected onto the map of biotopes. 
from Ruciane is linked to the population from Bolewice while the population from Supraśl is linked to the populations from Gubin and from Janów Lubelski. The populations from Spała and Rychtal are linked through the population from Janów Lubelski.

Isophen 0, delineated on the biotope map due to application of the Bryant's test (Bryant 1977) permitted to define geographic variability between the studied populations. Isophen 0 for the first discriminant variable (Fig. 7) separated northeastern populations from Miłomłyn, Ruciane and Supraśl and the populations from Bolewice and Gubin from the remaining populations. Isophen 0 for the second discriminant variable (Fig. 8) altered the classification of the population from Bolewice including it to the group of populations from Spała, Rychtal and Janów Lubelski. The north-eastern populations remained in a single group which could be defined as the North-Polish group.

\section{DISCUSSION}

Literature of the subject, providing results of testing the variability between Polish populations of Pinus sylvestris L., contains few papers only which deal with morphological and anatomical traits of needles (Sokołowski 1931, Zajączkowski 1949, Staszkiewicz 1970, Przybylski 1970, Bobowicz 1984). On the basis of the present results it may be concluded that the studied samples, collected from eight Polish populations of $P$. sylvestris L., are in great majority significantly differentiated. The highest values of the applied variability measures have been observed when one of the compared populations has involved Bolewice. This points to a marked divergence of the population as compared to the remaining ones. Some divergence has been observed all in respect to the population from Miłomłyn (Table 3, Figs. 2-5).
The populations from the area of Northern Poland: Miłomłyn and Ruciane and those from the area of Western Poland: Bolewice and Gubin form a single geographic group, as shown in Fig. 7, while the remaining populations, i.e. those from Supraśl, Rychtal, Spała and Janów Lubelski form the other group. The population distribution shown in Fig. 7 has resulted from drawing isophen 0 on the basis of values of the first discriminant variable, $\mathrm{U}_{1}$ (containing more than $54 \%$ information of the entire set of 15 needle traits). Values of determination coefficients between the first discriminant variables and the 15 needle traits indicate that practically only two traits participate in shaping the variable, i.e. the number of stomata on the convex side of the needle and the respective number on the flat of needle side. The two traits are, thus, responsible for the obtained pattern of geographical variability (Fig. 7). The isophen 0, drawn in Fig. 8 is associated with values of the second discriminant variable, $\mathrm{U}_{2}$. The distribution of studied populations into geographical groups resulting from the isophen 0 differs somewhat from the distribution detected in Fig. 8. A single geographical group includes Miłomłyn, Ruciane, Supraśl while the other includes Gubin, Spała, Bolewice, Rychtal and Janów Lubelski. On the basis of values of determination coefficients between needle traits and discriminant variables it may be concluded that the second discriminant variable $\mathrm{U}_{2}$ (close to $26 \%$ information of the applied set of 15 needle traits) is formed by needle length with slight involvement also of the numbers of stomata on each side of the needles. Thus, needle length is responsible for the detected population distribution (Fig. 8). Pines from Spała, Rychtal and Janów Lubelski, present in the same geographical group in the two discussed distributions are not significantly differentiated from each other. Population contrasts: Spała Janów Lubelski, Spała - Rychtal and Rychtal - Janów Lubel-

TABLE 3. Mahalanobis distances ( $\mathrm{D}_{\text {calc }}$ ) between 8 Polish populations of Pinus sylvestris $\mathrm{L}$. calculated on the basis of 15 needle traits with Hotelling $\mathrm{T}^{2}$ statistics $\left(\mathrm{T}^{2}\right.$ calc). $\mathrm{T}^{2}{ }_{0.05}$ - critical value of Hotelling $\mathrm{T}^{2}$ statistics. * - significant at the level of 0.05

$$
\mathrm{D}_{\text {calc }}=1.86, \mathrm{~T}_{\text {calc }}^{2}=57.35, \mathrm{~T}^{2} 0.05=171.6855
$$

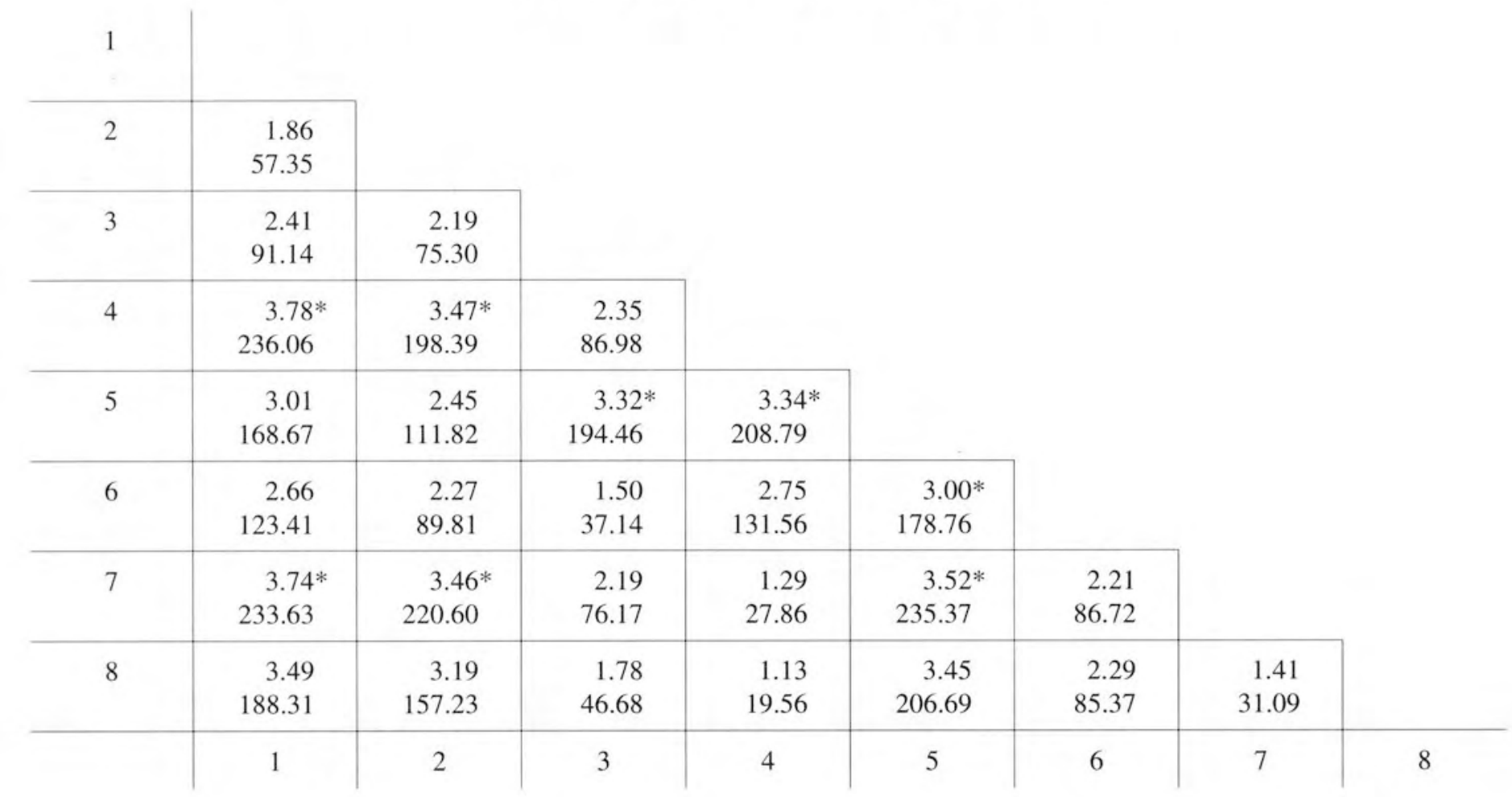



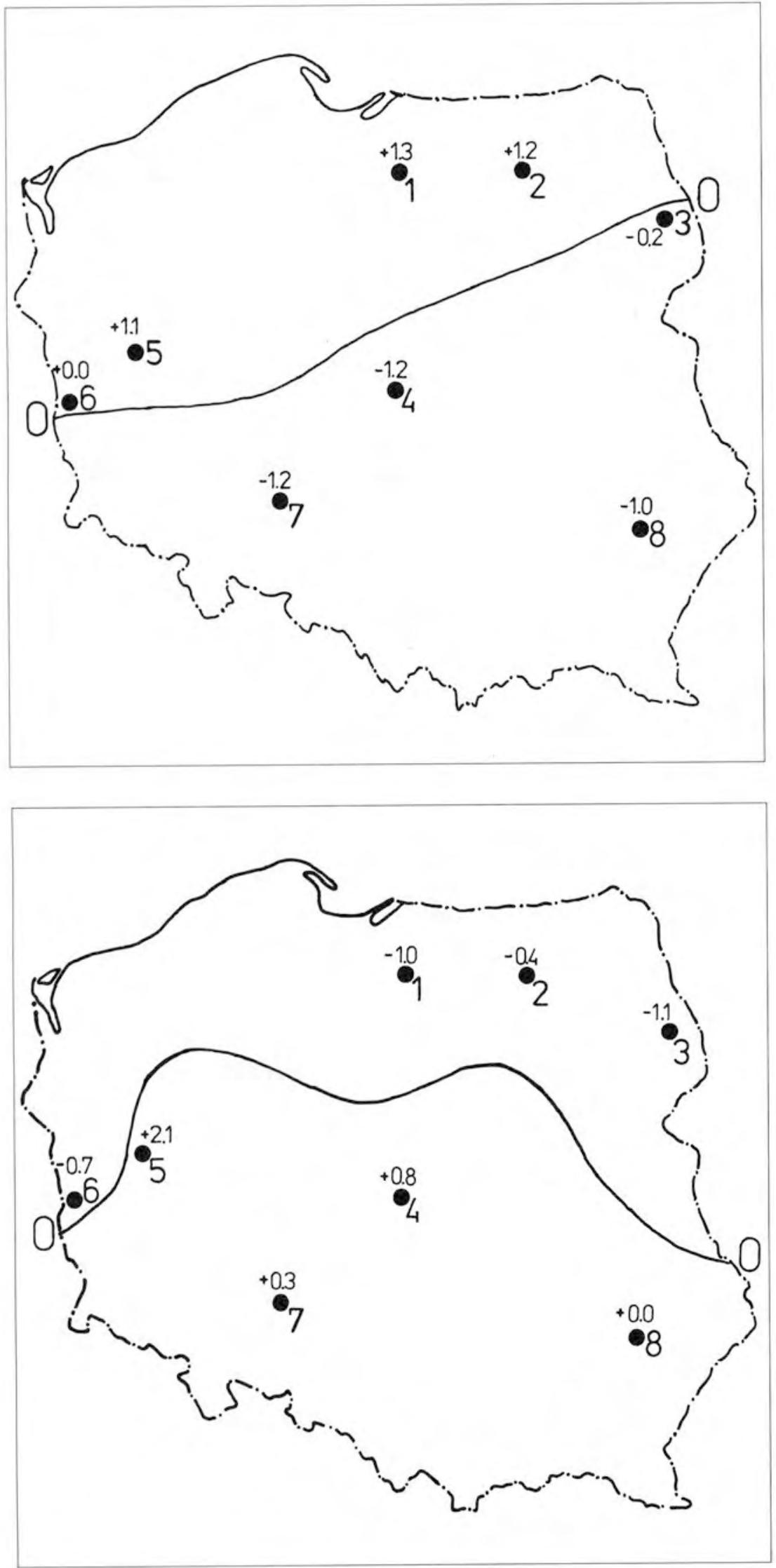

Fig. 7. Geographic variability of eight Pinus sylvestris L. populations (described in Fig. 1.) dectected using the Bryant's test (isophen 0) for the first discriminant variable.
Fig. 8. Geographic variability of eight Pinus sylvestris L. populations (described in Fig. 1.) dectected using the Bryant's test (isophen 0) for the second discriminant variable. ski (apart from the Supraśl - Gubin comparison) have been the only significantly undifferentiated contrasts in the multivariate analysis of variance.

The applied statistical test allows to find out that, out of 15 applied needle traits, three determine hidden variability of the eight populations of $P$ sylvestris $\mathrm{L}$,. (Table 2). The traits include needle length, the number of stomata on the flat side of the needle and the number of resin canals. In the set, needle length plays principal role. The numbers of stomata on each side of the needle and particularly those on the flat side and 
the number of resin canals are the traits which remain least correlated with the remaining ones. Needle length (except of the population from Miłomłyn) is significantly correlated with the width and the height of needle crossection in all populations. Variability coefficient (Table 1) of needle length ranges between $11.08 \%$ for the pine from Spała to $17.25 \%$ for the pine from Gubin. Variability coefficients for the number of stomata, both at the flat and on the convex sides of the needle, have never been lower than $5 \%$ or higher than $10 \%$. The highest values of the variability coefficient of the two traits (i.e. the numbers of stomata on each side of the needle) have been noted in pines from Bolewice. In respect to the number of resin canals, the pine from Janów Lubelski is most variable and the pine from Miłomłyn - the least variable one. The obtained results allow to ascribe the detected variability between the eight Polish populations of Pinus sylvestris L. mainly to the morphological traits of needles and to the number of resin canals. The studies on interpopulational variability and on variability of needle length will be continued.

\section{CONCLUSIONS}

1. Using hypothesis testing in multivariate analysis of variance, only 4 out of 28 contrasts, each comparing two out of eight examined populations, have proven to be significantly differentiated (Rychtal - Janów Lubelski, Supraśl Gubin, Spała - Janów Lubelski and Spała - Rychtal). Among the significantly differentiated contrasts, three have differed in respect to all principal variables: Miłomłyn - Spała, Bolewice - Janów Lubelski, Miłomłyn Janów Lubelski. The highest values of statistics $F$ have been reached by contrasts which included the population from Bolewice.

2. On the basis of the calculated Mahalanobis distances, 10 out of 28 links between 8 populations have been found significantly different $\left(\mathrm{T}^{2}\right.$ calc $\left.\mathrm{T}^{2} 0.05\right)$. Half of them pertained to links which included the population from Bolewice.

3. Miłomłyn and Bolewice have been the most divergent populations in the groupping on the basis of Euklidean distances.

4. Length of the needle, the number of stomata on the flat side of the needle and the number of resin canals exert decisive effect in differentiating the studied pine populations. Among the traits, needle length is distinguished by the respective value of statistics $\mathrm{F}$. The remaining 12 variables are of associative significance.

5. On the basis of the Bryant's test the studied populations have been found to belong to two geographic groups: the North-Polish one, comprising the north-eastern pine populations from Miłomłyn, Ruciane and Supraśl plus the Gubin population and the South-Polish group including Spała, Rychtal and Janów Lubelski populations. The population from Bolewice belonged to the former group in respect to the number of stomata on the flat and the convex sides of the needle but to the latter group in respect to the needle length.

6. The obtained results show that the Bolewice population is the most divergent population.

\section{ACKNOWLEDGEMENTS}

The authors would like to express their thanks to Miss Anna Sufryd, M.Sc., for her excellent technical help. This study was financed by grant No. 15.3.3.078.01. from the Forest Research Institute.

\section{LITERATURE CITED}

BOBOWICZ M.A. 1984. Variability of needles in Polish populations of Scots pine (Pinus sylvestris L.). Bull. Soc. Amis. Sci. Lett. Poznań, Ser. D, 24: 97-104.

BOBOWICZ M.A., KORCZYK A.F. 1994. Variability of 8 Polish populations of Pinus sylvestris L. expressed in traits of cones. Acta Soc. Bot. Pol. (in print).

BRYANT E.H. 1977. Morphometric adaptation of the housefly Musca dom esticaL. in the United State. Evolution 31: 580-596.

CALIŃSKI T. 1970. Wielozmienna analiza wariancji i pokrewne metody wielowymiarowe. Materiały Kursu Szkoleniowego PTB i Wydziału V PAN, Warszawa.

CALIŃSKI T., CZAJKA S., KACZMAREK Z. 1975. Principle component analysis and its application. (In Polish). Roczniki Akademii Rolniczej w Poznaniu. Algor. Biometr. Statyst. 36: 159-185.

CALIŃSKI T., DYCZKOWSKI A., KACZMAREK Z. 1974. The selection of variables for the analysis of multivariate experimental data. (In Polish). Roczniki Akademii Rolniczej w Poznaniu. Algor. Biometr. Statyst. 28:117-142.

CALIŃSKI T., DYCZKOWSKI A., KACZMAREK Z. 1976. Testing the hypotheses in multivariate analysis of variance. (In Polish). Roczniki Akademii Rolniczej w Poznaniu. Algor. Biometr. Statyst. 44: 76-95.

CALIŃSKI T., KACZMAREK Z. 1973. Metody kompleksowej analizy doświadczenia wielocechowego. Wydz. V PAN i PTB, Warszawa, Wrocław.

CERANKA B., CHUDZIK H., CZAJKA S., KACZMAREK Z. 1976. Multivariate analysis of variance for one-way classification. (In Polish). Roczniki Akademii Rolniczej w Poznaniu. Algor. Biometr. Statyst. 86: 3-21.

CHODZICKI E. 1978. Badania proweniencyjne nad wzrostem Pinus sylvestris L. z terenów PTL w reglu dolnym Karpat w latach 19661972. Zesz. AR w Krakowie, 144: 23-36.

CIERNIEWSKI M., PRZYBYLSKI T. 1978. Variability in growth characters of 10-year old Scots pine (Pinus sylvestris L.) of Polish provenances. Arbor. Korn. 23: 171-183.

GIERTYCH M. 1979. Summary of results on Scots pine (Pinus sylvestris L.) height growth in IUFRO provenance experiments. Silvae Genetica 28: 136-152.

GIERTYCH M. 1980. Polish races of Scots pine, Norway spruce and European larch in international provenance experiments. Arbor. Kórn. 25: 135-160.

GUNIA S. 1973. Growth of 16 Polish provenances of Scots pine on an experimental area in Forest Range Lipce near Rogów. Proceeding from the IUFRO Symposium on genetics of Scots pine. KórnikWarszawa.

KAROŃSKI M., CALIŃSKI T. 1973. Grouping in multivariate populations on the basis of Euklidean distances. (In Polish). Algor. Biometr. Statyst. 17: 117-129.

KOCIE CKI S. 1973. Provenance research on Scots pine conducted by the Forest Research Institute. Proceedings from the IUFRO Symposium on genetics of Scots pine Kórnik-Warszawa.

KORCZYK A. 1975. Badania nad wartością genetyczną drzew doborowych sosny wykorzystywanych do zakł adania plantacji nasiennych. Dokumentacja IBL.

KRZAKOWA M. 1979. Interpopulational enzyme variability of natural Scots pine (Pinus sylvestris L.) populations. (In Polish). Adam Mickiewicz University Press 17: 1-43.

KRZAKOWA M. 1980. The most frequent genotype as indicator of interpopulational differentiation in Scots pine (Pinus sylvestris L.). 
Procc. IUFRO Symp. on Scots Pine forestry of the future Working Party in Kórnik, Poland.

KRZAKOWA M. 1982. Genetic differentiation of Scots pine populations.1. Genotypes. Silva Fennica 16: 200-205.

KRZAKOWA M., URBANIAK L., KORCZYK A. 1990. Mono- and polygenic variability within natural Scots pine (P. sylvestris L.) populations. In: H. H. Hattemer, S. Fineschi, F. Cannata, M. E. Malvolti (eds.). Biochemical Markers in the Population Genetics of Forest Trees. SPB Acad. Publishing. The Hague, 85-89.

KRZYŚKO M. 1979. Discriminant variables. Biometrical Journal 21: 227-241.

KRZYŚKO M. 1982. Discriminant analysis. (In Polish). Adam Mickiewicz University Press 6: 1-98.

MARCET E. 1967. Über den Nachweis spontaner Hybriden von Pinus mugo Turra und Pinus sylvestris L. auf Grund von Nadelmerkmalen. Ber. Schweiz. Bot. Ges. 77: 314-361.

PRZYBYLSKI T. 1970. Zmienność sosny zwyczajnej (Pinus sylvestris L.) polskich proweniencji. Zakł ad Dendr. i Arbor. PAN w Kórniku.

PRZYBYLSKI T. 1972. Variability of Scots pine (Pinus sylvestris L.) of Polish provenances. Arbor. Kórn. 17: 121-167.
RZEŹNIK Z. 1973. Studies on Scots pine provenances and results obtained in the Siemianice experimental area. Proceeding from the IUFRO Symposium on genetics of Scots pine. Kórnik-Warszawa.

SABOR J., STACHNIK E. 1990. Survival and growth of various Scots pine provenances in site conditions of Sącz Beskid exemplified on comparative area in Polany near Grybów. Sylwan 134: 11-26.

SOKOŁOWSKI S. 1931. Prace biometryczne nad rasami sosny zwyczajnej (Pinus sylvestris L.) na ziemiach Polski. Prace Rol.-Leśne, PAU, 5.

STASZKIEWICZ J. 1970. Systematics and variability. In: S. Biał obok (ed.) Sosna zwyczajna Pinus sylvestris L. Arbor. Kórnickie pp. 55-77, PWN, Warszawa-Poznań.

TYSZKIEWICZ S., KOCIĘCKI S., JANSON L. 1967. Doskonalenie metod selekcji i techniki pozyskiwania nasion sosny pospolitej. Dokumentacja IBL.

ZAJĄCZKOWSKI M. 1949. Studia nad sosn ą zwyczajną w Tatrach i Pieninach. Spraw. Kom. Fizjogr. PAU, 20, Kraków.

\title{
MIĘDZYPOPULACYJNA ZMIENNOŚĆ PINUS SYLVESTRIS L. OŚMIU POLSKICH STANOWISK WYRAŻONA ZA POMOCĄ MORFOLOGICZNYYCH I ANATOMICZNYCH CECH IGIEE
}

\begin{abstract}
STRESZCZENIE
Z 272 rosnących drzew sosny zwyczajnej reprezentujących 8 polskich populacji zebrano dwuletnie igły, które opracowano pod względem 15 cech morfologicznych i anatomicznych. Dane biometryczne poddano kompleksowej wielocechowej analizie statystycznej, za pomocą której starano się opisać zmienność między ośmioma populacjami. Wykonano wielozmienną analizę wariancji wraz $\mathrm{z}$ testowaniem hipotez statystycznych, analizę zmiennych dyskryminacyjnych i obliczono odległości Mahalanobisa, których istotność oceniono za pomocą statystyki $\mathrm{T}^{2}$ Hotellinga. Na bazie najkrótszych odległości Mahalanobisa zbudowano dendryt, a na podstawie odległości Euklidesa przeprowadzono grupowanie hierarchiczne. Stwierdzono, że zdecydowana większość porównań między populacjami jest statystycznie istotna. Najbardziej odrębną populacją okazały się Bolewice. Głównymi cechami dyskryminującymi badane populacje są: długość igły, liczba szparek na płaskiej stronie igły i liczba kanałów żywicznych. Za pomocą testu Bryant'a wykryto, że zbadane populacje należą do dwóch grup geograficznych: północno- i południowo-polskiej.
\end{abstract}

SŁOWA KLUCZOWE: sosna zwyczajna, populacje, igły, zmienność, analizy wielozmienne. 